\author{
Aneta KRZEWIŃSKA ${ }^{1}$
}

\title{
INNOWACJE W BADANIACH SPOŁECZNYCH ${ }^{2}$
}

Innowacje są rezultatem ewolucji zjawisk, przy czym podlegają im zarówno zjawiska społeczne, jak i gospodarcze. Nowe zjawiska, tak interesujące dla naukowców, często nie mogą być badane przy użyciu „starych” metod badawczych. Może to wynikać z jednej strony $\mathrm{z}$ niedostosowania samej aparatury pomiarowej, a $\mathrm{z}$ drugiej $\mathrm{z}$ niedopasowania procedur badawczych do nowych zjawisk. W wyniku tak rozumianej nieadekwatności pomiędzy zjawiskami a technikami służącymi do ich badania, socjologowie mogą postąpić na dwa sposoby: zrezygnować z badania tego lub wprowadzić zmiany w obrębie samej metodologii. Pierwsza $\mathrm{z}$ tych strategii jest bardzo rzadko stosowana, natomiast druga $\mathrm{z}$ nich przyczynia się do wprowadzenia innowacji w samych metodach badań społecznych. Celem artykułu jest prezentacja zmian, które zachodzą $\mathrm{w}$ badaniach społecznych a związanych $\mathrm{z}$ innowacjami w obrębie socjologicznego instrumentarium badawczego. Refleksji zostaną poddane kierunki tych zmian wraz z próbą oceny ich wpływu na jakość badań społecznych i zbieranych w ich trakcie materiałów. Źródłami danych będących podstawą do tych rozważań będą między innymi uczestnictwo w projektach badawczych, własne doświadczenia badaczy zjawisk społecznych oraz studia nad literaturą przedmiotu. Zmiany w obrębie badań społecznych mogą być różnorodne, ale do najczęściej spotykanych należą: modyfikacje istniejących technik badawczych związane przede wszystkim z rozwojem technologii (np. techniki otrzymywania materiałów wspomagane komputerowo), wprowadzanie nowych technik czy to z innych nauk społecznych, czy to z praktyki pozanaukowej (techniki deliberacyjne), opracowanie metodologiczne pewnych wcześniej stosowanych procedur, które zyskują miano techniki badawczej (autoetnografia), a także wyróżnienie w procesie prowadzenia badań poszczególnych etapów tego procesu i nadanie im statusu techniki (np. desk research).

Słowa kluczowe: innowacje, badania społeczne, technika badań, metodologia badań społecznych.

\footnotetext{
${ }^{1}$ Dr hab. Aneta Krzewińska, Katedra Metod i Technik Badań Społecznych, Wydział Ekonomiczno-Socjologiczny Uniwersytet Łódzki, ul. Rewolucji 1905 r. nr 41/43, 90-214 Łódź; e-mail: aneta.krzewinska@uni.lodz.pl.

Aneta Krzewińska, DSc, PhD, Department of Methods and Techniques of Social Research, Faculty of Economics and Sociology, University of Lodz, ul. Revolution of 1905. No. 41/43, 90-214 Łódź; e-mail: aneta.krzewinska@uni.lodz.pl.

2 Treści wyrażone w artykule są opiniami autorki i nie przedstawiają stanowiska organów Narodowego Banku Polskiego.

Projekt pt. Forum Dyskusyjne - Pomiar i ocena zjawisk ekonomicznych i społecznych (MASEP 2017) realizowany jest z Narodowym Bankiem Polskim w ramach edukacji ekonomicznej.
} 


\section{BADANIE SPOŁECZNE JAKO PROCES}

Badanie społeczne ${ }^{3}$ ma procesualny charakter, co pozwala na wskazanie poszczególnych etapów i zadań, które muszą zostać zrealizowane, aby zakończyło się ono zebraniem danych pozwalających na udzielenie odpowiedzi na postawione w badaniu pytania problemowe ${ }^{4}$. W badaniach weryfikacyjnych (których zadaniem jest weryfikacja wcześniej postawionych hipotez) wyróżnia się trzy zasadnicze fazy: przygotowawczą, terenową i opracowania. Pierwszy z etapów obejmuje następujące czynności: przygotowanie koncepcji badań $^{5}$, dobór i przygotowanie technik badawczych oraz dobór zjawisk, z którymi badacz lub jego współpracownicy wejdą w kontakt przy zbieraniu materiałów. Faza druga związana jest ze zbieranie materiałów w terenie, a w ramach trzeciej wskazuje się na: krytykę, selekcję i wstępne opracowanie materiałów, właściwe opracowanie materiałów powiązane z interpretacją wyników oraz przygotowanie raportu prezentującego badania i ich rezultaty.

Każda z wyżej wymienionych faz badawczych może podlegać pewnym zmianom związanym przede wszystkim z usprawnianiem, ulepszaniem czy unowocześnianiem poszczególnych czynności, które muszą być w jej trakcie zrealizowane. A więc w trakcie planowania, prowadzenia i opracowywania badań wprowadzane bywają modyfikacje, które czasami zostają określone mianem innowacji. I tak, w trakcie fazy przygotowawczej mamy na przykład do czynienia z nowymi sposobami doboru jednostek (osób, instytucji, organizacji, zjawisk, zbiorowości itp.) do badań. Tutaj z pomocą socjologom przychodzą statystycy tworzący nowe strategie doboru, pracujący nad procedurami pozwalającymi ,zastępować” lub uzupełniać jednostki niedostępne podczas badania. W tej samej fazie badań coraz częściej wykorzystywane jest odpowiednie oprogramowanie komputerowe pozwalające na skryptowanie narzędzia badawczego umożliwiającego np. automatyzację zapisów związanych z wyborem liczby odpowiedzi (co dotyczy pytań z kafeterią oferujących badanym wybór więcej niż jednej odpowiedzi), kontrolę reguł przejścia itp. Faza terenowa pozwala na wprowadzanie innowacyjnych technik otrzymywania materiałów, co zostanie dokładniej omówione w dalszej części tego artykułu. Etap opracowania rezultatów badań to przede wszystkim stworzenie odpowiedniego oprogramowania wykorzystywanego zarówno w analizie danych ilościowych (badacze społeczni mogą korzystać z różnych pakietów statystycznych), jak i do analizy materiału jakościowego, gdy programy komputerowe ułatwiają badaczom ,poruszanie się” w ogromnej ilości materiału (np. w setkach stron transkrypcji

\footnotetext{
${ }^{3}$ Pisząc o badaniach społecznych mam na myśli przede wszystkim badania prowadzone przez socjologów (taką dyscyplinę naukową reprezentuję), ale jestem przekonana, że pewne aspekty tych badań poruszane w tym artykule są ważne również dla innych nauk społecznych.

${ }^{4}$ Pytania problemowe są zasadniczym elementem problematyki badań i dotyczą zjawisk społecznych (bądź wybranych i określonych aspektów tych zjawisk), które interesują badacza. Mogą mieć różny poziom ogólności, przybierać różne formy (otwarte/zamknięte) i rodzaje (o system/o zbiór/o zależności). Celem badacza jest udzielenie możliwie dobrze uzasadnionych odpowiedzi na pytania problemowe.

${ }^{5}$ Koncepcja badawcza, jak pisze Jan Lutyński w książce pt. Metody badań społecznych jest zbiorem ustaleń, pytań, założeń dotyczących celu i głównych faz procesu badawczego i projektu opracowania wyników. Zawarte w niej ustalenia mogą mieć różną formę: twierdzeń, dyrektyw, pytań, co zależy od części, której dotyczą. Sama koncepcja jest zasadniczą częścią projektu badań, w którym znajdują się również rozstrzygnięcia dotyczące spraw organizacyjnych i finansowych oraz harmonogram działań.
} 
z wywiadów swobodnych), a także do łączenia ze sobą materiałów mających różną formę, np. filmów, tekstów, zdjęć, nagrań audio itp.

\section{INNOWACJE W METODOLOGII BADAŃ SPOŁECZNYCH}

Innowacje (również te pojawiające się w obrębie badań społecznych) można opisać jako zmiany, które są celowe oraz świadomie wprowadzone, a także odnoszą się do określonego czasu, konkretnych warunków, powstały w wyniku pewnych niekonwencjonalnych działań jednostek, najczęściej wiążą się z dodatkową pracą i pewnym ryzykiem porażki, a także mogą mieć formę materialną (np. jest to konkretny przedmiot) lub być ideą ${ }^{6}$ (opisem procesu realizacji pewnych działań). Zawsze też istnieje jakiś adresat innowacji, do którego jest ona kierowana ${ }^{7}$. Cechuje je nowatorstwo w tym sensie, że są one związane z nowymi pomysłami (odnoszącymi się do nowych produktów, usług, działań, procedur itp.) i zostały wprowadzone po to, by odpowiedzieć na wcześniej niezaspokojone potrzeby jednostek, grup, instytucji, organizacji ${ }^{8}$.

Na użytek tego artykułu przyjmuję, że innowacje są zespołem zjawisk, a także procesów, w których można wyróżnić (powiązane ze sobą) następujące etapy: zidentyfikowanie potrzeb (niemożność ich zaspokojenia lub niezadowolenie ze sposobu ich realizacji za pomocą dotychczas istniejących środków), generowanie idei związane z tworzeniem pomysłów odpowiadających na zidentyfikowane potrzeby, próbne wprowadzenie innowacji wraz z ewentualnym udoskonalaniem, wdrożenie innowacji oraz stopniowe zwiększanie jej zasięgu często powiązane $\mathrm{z}$ wprowadzeniem trwałych zmian społecznych. Jeśli takie rozumienie innowacji ,przyłożymy” do metodologii badań społecznych, to będziemy mogli mówić o zmianach w poszczególnych etapach badania wynikających z potrzeb badaczy społecznych, którzy chcą realizować badania szybciej, sprawniej, lepiej: po to, by z jednej strony wzrastała efektywność procesu badawczego, a z drugiej by utrzymać wysoką jakość otrzymywanego materiału. W metodologii badań socjologicznych można zatem zauważyć tendencje do pojawiania się innowacji powiązanych z:

1. usprawnieniem pewnych elementów (np. proces zbierania informacji - faza terenowa - został znacznie przyspieszony poprzez wykorzystanie telefonów do przeprowadzania wywiadów kwestionariuszowych);

2. poprawieniem jakości procedury badawczej, jej fragmentów lub otrzymanych rezultatów (np. odpowiedzią na niskie odsetki realizacji w badaniach surveyowych jest zastosowanie badań Mix Mode ${ }^{9}$;

\footnotetext{
${ }^{6}$ Martyna Wronka-Pośpiech w artykule opisującym innowacje społeczne zauważa, że choć innowacje najczęściej kojarzone są z pewnymi zmianami mającymi postać materialną, to jednak ,,[S]tosunkowo od niedawna dostrzega się także znaczenie innych rodzajów innowacji, najczęściej określanych mianem organizacyjnych (...) lub nietechnologicznych (...), bądź innowacji miękkich (...). Ze studiów literaturowych wynika, że coraz żywsze jest zainteresowanie rolą innowacji zarządczych (...), organizacyjnych (...), architektonicznych (..), etnicznych (...), rozpraszających (...) czy ekoinnowacji” [M. Wronka-Pośpiech, Innowacje społeczne - pojęcie i znaczenie, Studia Ekonomiczne. Zeszyty Naukowe Uniwersytetu Ekonomicznego w Katowicach, nr 212/2015, s. 124].

7 A. Olejniczuk-Merta, Innowacje społeczne, „Konsumpcja i Rozwój” 2013, nr 1, s. 23.

${ }^{8}$ G. Mulgan, Social innovation: What it is, Why it matters, How it can be accelerated, London 2006.

${ }^{9}$ Procedura Mix Mode polega na uzyskiwaniu od badanych tych samych informacji przy wykorzystaniu różnych technik otrzymywania materiałów, np. CWI, CATI, CAPI, PAPI w tym samym badaniu.
} 
3. nowymi zjawiskami społecznymi, których nie można zbadać sprawdzonymi, ale jednak „starymi” metodami, ponieważ są za pomocą tych metod nieuchwytne, np. trudno badać komunikowanie się na portalach społecznościowych bez wykorzystania technologii komputerowej i sieci internetowej.

Zdając sobie sprawę z tego, że innowacje w metodologii nauk społecznych (w tym także w socjologii) odnoszą się do całego pola badawczej działalności i mogą im podlegać wszystkie czynności składające się na cały proces badawczy, w dalszej części ograniczę się tylko do tych innowacyjnych zmian, którym podlegają techniki otrzymywania materiału. Przy czym przywiązana jestem do sposobu zdefiniowania pojęcia technika otrzymywania materiału zaproponowanego przez Jana Lutyńskiego, który pisał: ,postępowanie badawcze związane z otrzymywaniem materiałów (...) stanowi rozbudowany kompleks czynności zakładających posługiwanie się określonymi środkami technicznymi i intelektualnymi. Cały ten kompleks ujęty jest w określone reguły"10. Źródła innowacji w przypadku technik otrzymywania materiałów są różnorodne i można wśród nich wyróżnić: innowacje technologiczne, innowacje związane z przeniesieniem technik z jednej dziedziny naukowej do innej, innowacje związane z zapożyczeniami z działalności pozanaukowej oraz innowacje polegające na wydzieleniu pewnych czynności z procesu badawczego i nadanie im statusu nowej techniki ${ }^{11}$.

Innowacje technologiczne związane są przede wszystkim z wykorzystaniem komputerów w procesie gromadzenia danych. Informatyzacja procesu badawczego pozwoliła na przyspieszenie zarówno etapu zbierania materiału (np. w przypadku wywiadów prowadzonych przez telefon ze wspomaganiem komputerowym faza terenowa $z$ tygodni, a nawet miesięcy, została skrócona do dni czy godzin), ale również dają możliwość zintensyfikowania fazy opracowania (odpowiedzi na pytania w technikach wspomaganych komputerowo są automatycznie zapisywane w bazie i nie trzeba zatrudniać kodera, który przełożyłby zapisane w papierowych kwestionariuszach odpowiedzi respondentów na symbole najczęściej liczby - na których później wykonuje się obliczenia z użyciem pakietów statystycznych). W badaniach jakościowych stosuje się wynalazki technologiczne do zbierania materiału poprzez na przykład wykorzystanie nagrań wideo w wywiadach dotyczących życia badanych ${ }^{12}$.

Techniki opracowane i stosowane w jednej dyscyplinie naukowej mogą być przejmowane i wprowadzane do innych dyscyplin. Te zapożyczenia dotyczą bardzo często takich nauk jak: etnografia, antropologia, nauki polityczne, psychologia społeczna. Przykładem takiego ,pokojowego zawłaszczenia” jest przejęcie metod antropologicznych przez zarządzanie (m.in. antropologiczne badania biznesu prowadzone i rozpowszechniane przez socjologów $)^{13}$. Są to przede wszystkim badania terenowe przy użyciu wielu technik i narzędzi, gdzie dominującą rolę odgrywa obserwacja uczestnicząca wspomagana różnego typu wywiadami, analizą dokumentów itp. „W badaniu terenowym zmysłowemu poznaniu podlegają niezliczone akty - powtarzalne wzory zachowań, »antyzachowania«, interakcje,

10 J. Lutyński, Metody badań społecznych, Łódź 1994, s. 111.

11 Por. M. Xenitidou, N. Gilbert, Innovations in social research methods, University of Surrey, 2009, http://epubs.surrey.ac.uk/id/eprint/2271 (dostęp: 15.11.2017 r.).

12 M. Banks, Materiaty wizualne w badaniach jakościowych, Warszawa 2009, s. 122-135.

${ }^{13} \mathrm{~K}$. Konecki, Kultura organizacyjna japońskich przedsiębiorstw przemysłowych. Studium socjologiczne, Łódź 1994; M. Kostera, Antropologia organizacji. Metodologia badań terenowych, Warszawa 2005; Cz. Sikorski, Miasta, kultury, organizacje, Łódź 2005. 
przedmioty, relacje czasowe i przestrzenne oraz wiele innych - które zwykło się określać jako manifestacje »kultury organizacji $« " 14$.

Trzecia grupa innowacji dotyczy elementów procesu badawczego, które wcześniej były realizowane jako pewien sposób badawczy ${ }^{15}$, ale po odpowiednim opracowaniu, opisaniu zyskały status techniki. Na przykład - zapoznanie się z materiałami na temat tego, co zamierzamy badać, przejrzenie literatury tematu, analiza wcześniejszych badań (zarówno ich metodologii, jak i rezultatów) dawniej poprzedzała każde akademickie badanie społeczne. Obecnie cała ta procedura zyskała miano osobnej techniki badawczej - desk research i jest oferowana jako odrębne działanie badacza, po którym nie musi następować faza terenowa. Takie podejście jest tożsame z tym, co Zofia Bednarowska określa mianem zasadniczego desk research, czyli takich czynności, które nie wymagają odwołania się do innych (reaktywnych) badań terenowych i ,,[W] takim przypadku służy najpierw rozeznaniu w badanej tematyce, a później odpowiedzi na postawione pytania badawcze. Kluczowe w tym przypadku jest wyszukiwanie informacji według ściśle określonych celów badawczych: ogólnych i szczegółowych"16.

I wreszcie, badacze szukają czasami inspiracji w działaniach podejmowanych przez ludzi niezwiązanych z nauką. W taki sposób - podglądając np. działaczy społecznych - wprowadzono do nauk społecznych techniki wykorzystujące partycypację badanych. Prężnie rozwijające się action research polegają na łączeniu kompetencji badaczy społecznych z zaangażowaniem członków jakiejś wspólnoty lokalnej po to, by zbierać informacje wraz z badanymi a nie tylko o badanych. „Lokalni uczestnicy są ekspertami, jeśli chodzi o ich własne życie, problemy, sytuacje, a ich znajomość szczegółowych kwestii związanych z danymi problemami oraz możliwości działania są nieocenione"17. Badani uczestniczą więc w uszczegóławianiu problematyki, zbieraniu informacji, opracowywaniu zgromadzonych materiałów, analizowaniu i interpretowaniu danych, formułowaniu wniosków, a w przypadku, gdy badania mają charakter aplikacyjny również w tworzeniu rekomendacji do pewnych działań.

W dalszej części artykułu opisane zostaną dwa przykłady innowacji związanych z technikami otrzymywania materiałów: innowacje związane z wprowadzeniem technologii oraz innowacyjne techniki przenoszone na grunt nauki z działalności pozanaukowej. Wybór tych dwóch zagadnień związany jest z moimi własnymi doświadczeniami badawczymi, a mianowicie: $\mathrm{z}$ udziałem w projekcie badawczym ${ }^{18}$, w którym testowano innowacje technolo-

${ }^{14}$ E. Jagiełło, Antropolog w organizacji. Zapiski z badań terenowych, „Etnografia Polska”, t. LVI, 2012, z. 1-2, s. 161.

${ }^{15}$ Sposoby badawcze tym różnią się od technik, że jako takie nie są ujęte w spisane i tym samym utrwalone dyrektywy. Można się z nimi zapoznać tylko poprzez współuczestniczenie w pewnych etapach procesu badawczego, obserwowanie innych badaczy, naśladowanie ich postępowania.

${ }^{16}$ Z. Bednarowska, Desk research - wykorzystanie potencjatu danych zastanych w prowadzeniu badań marketingowych i spotecznych, „Marketing i Rynek” 2015, nr 7, s. 19.

${ }^{17}$ D.J. Greenwood, Action research, czyli o badaniach $w$ działaniu [w:] D. Jemielniak, Badania jakościowe. Podejścia i teorie, Warszawa 2012, s. 116-117.

${ }^{18}$ Opis założeń teoretycznych tego badania znajduje się w publikacji: K. Grzeszkiewicz-Radulska, A. Krzewińska, Wykorzystanie nowoczesnych technologii w ankietach wspomaganych komputerowo [w:] Technologiczno-społeczne oblicza XXI wieku, red. D. Gałuszka, G. Ptaszek, D. Żuchowska-Skiba, Kraków 2016. 
giczne oraz z próbą zaimplementowania technik deliberacyjnych do socjologicznego instrumentarium badawczego ${ }^{19}$.

\section{INNOWACJE TECHNOLOGICZNE TECHNIK OTRZYMYWANIA MATERIALÓW}

Innowacje technologiczne dotyczące technik otrzymywania materiałów najczęściej polegają na unowocześnianiu dobrze znanych i często stosowanych technik poprzez wykorzystanie nowych technologii ${ }^{20}$. Takie aktualizacje przeszły przede wszystkim techniki wywiadu kwestionariuszowego, np. wywiad PAPI (paper and pencil personal interview) po zastosowaniu komputerów na etapie zbierania materiałów przeobraził się w wywiad CAPI (computer assisted personal interview) a bazą dla wywiady CATI (computer assisted thelephone interview) były wywiady kwestionariuszowe przez telefon. $\mathrm{Z}$ inną sytuacją mamy do czynienia w przypadku takich technik, które nie posiadały wersji „,nietechnologicznych", ponieważ na ich stworzenie pozwoliło dopiero pojawienie się pewnych udoskonaleń technologicznych - np. wprowadzenie wybierania tonowego w telefonach stacjonarnych (i istnienie takiego wybierania w telefonach komórkowych) dało możliwość przeprowadzania krótkich badań poziomu zadowolenia klientów z obsługi przez pracowników danej firmy. Techniką stosowaną w tym przypadku jest IVR (interactive voice response), którą opisywana jest jako odpersonalizowany sposób pozyskiwania ważnych informacji drogą telefoniczną, przy czym badani udzielają odpowiedzi albo za pomocą klawiatury telefonu (metoda popularniejsza zwana touch tone IVR), albo udzielając odpowiedzi ustnie (wtedy konieczny jest program do rozpoznawania głosu). Podobną techniką jest TDE ${ }^{21}$ (touch tone data entry), za pomocą której bada się m.in.: przedsiębiorców (informujących o liczbie zatrudnionych, zwalnianych pracowników), członków gospodarstw domowych (np. na temat ich wydatków, korzystania z określonych usług), respondentów w badaniach zachowań (np. związanych z ryzykownymi zachowaniami seksualnymi) ${ }^{22}$.

${ }^{19}$ Zob. A. Krzewińska, Deliberacja. Teoria - metodologia - praktyka, Łódź 2016.

${ }^{20}$ A. Krzewińska, K. Grzeszkiewicz-Radulska, Klasyfikacja sondażowych technik otrzymywania materiatów, „Przegląd Socjologiczny” 2013, t. 62/1.

${ }^{21}$ Osoby biorące udział w badaniu mogą zadzwonić pod dostarczony im numer i udzielić odpowiedzi na wcześniej nagrane pytania, poprzez naciskanie odpowiednich przycisków telefonu. W części aranżacyjnej do tych badań potencjalnemu respondentowi przekazuje się instrukcję postępowania oraz nadaje numer identyfikacyjny potrzebny do zalogowania się do systemu.

22 Zob.: S.J. Blumberg, M.L. Cynamon, Respondent Acceptance of Touch-Tone Data Entry in Cognitive Interview on HIV/STD Behaviors, 2000, www.fcsm.gov/99papers/ (dostęp: 25.06. 2013 r.); K.W. Robertson, J. Hatch-Maxfield, Data Collection in the U.S. Bureau of Labour Statistics' Current Employment Statistics Survey, wystąpienie przygotowane na konferencję w Genewie (31 października - 2 listopada), Seminar on New Frontiers for Statistical Data Collection, http://www.unece.org/fileadmin/DAM/stats/, 2012 (dostęp: 25.06 .2013 r.), R.B. McKay, E.L. Robinson, A.B. Malik, Touch-Tone Data Entry for Household Surveys: Research Findings and Possible Applications, 1994, www.bls.gov/ore/pdf/cp940080.pdf (dostęp 25 czerwca 2013 r.), M.P. Couper, Technology and the survey interview/questionnaire, F.G. Conrad, M.F. Schober (ed.), Envisioning the survey interview of the future, New York 2008; J. Bloom, The Speech IVR as a Survey Interviewing Methodology [w] Envisioning the Survey Interview of the Future, red. F.G. Conrad, M.F. Schober, New York 2008. 
Zdecydowanie ciekawsze są jednak zmiany zachodzące wśród technik o wysokim stopniu standaryzacji opartych na komunikowaniu się pośrednim - technik ankiety. Zmiany te związane są przede wszystkim z wprowadzanie do CAWI (computer assisted web interviewing) oraz CASI (computer assisted self interviewing) różnych elementów, które do tej pory odnosiły się do technik wywiadu kwestionariuszowego i związane były z osobą ankietera. Tego typu próby innowacji w procedurach zbierania materiału zostały zastosowane w projekcie, w którym badano wpływ różnych odmian ankiety internetowej CAWI na wartość uzyskiwanych danych ${ }^{23}$. Respondentami w badaniu byli losowo dobrani studenci Uniwersytetu Łódzkiego, których rekrutowano na dwa sposoby: w kontaktach face-to-face do wywiadów kwestionariuszowych CAPI oraz za pomocą zaproszenia wysyłanego e-mailem do badań CAWI. W sumie przebadano 900 osób, z których: po 200 badanych wypełniało różne rodzaje ankiety CAWI oraz wzięło udział w wywiadzie CAPI i dodatkowo 100 osób przebadano za pomocą wersji „MY” ankiety internetowej (dalej opisanej). W badaniu zastosowaliśmy 5 różnych scenariuszy, które reprezentowały kolejne poziomy zabiegów humanizujących procedurę badawczą (humanizing cues). Technika CAWI-MY (bez stosowania jakichkolwiek zabiegów humanizujących) zakładała, że respondenci widzą na ekranie komputera treść pytania wraz z odpowiedziami, przy czym pytania zostały zadane w pierwszej osobie liczby mnogiej (np. Przedstawimy Ci kilka rodzajów zajęć. W każdym przypadku zakładamy, że osoba, która je wykonuje, robi to z własnej woli i otrzymuje za to satysfakcjonujace wynagrodzenie finansowe. Jak oceniasz te zajęcia? Czy Twoim zdaniem...). W odmianie CAWI-IMIĘ zaimek my został zastąpiony formą żeńską lub męską czasownika (np. Teraz chciałbym zapytać Cię o Twoje poglądy w różnych kwestiach społeczno-politycznych. W jakim stopniu zgadzasz się bądź nie zgadzasz z następujacymi stwierdzeniami? lub Teraz chciałabym zapytać Cię o Twoje poglądy w różnych kwestiach społeczno-politycznych. W jakim stopniu zgadzasz się bądź nie zgadzasz z następujacymi stwierdzeniami?). Wyższy stopień zabiegów humanizujących reprezentowała ankieta CAWI w wersji ze zdjęciem ankietera. Oprócz zdjęcia badany widział na ekranie również treść pytania i listę możliwych odpowiedzi. Ostatnią odmianą ankiety internetowej była CAWI-FILM, w której respondent, aby zapoznać się z pytaniem, musiał obejrzeć film z ankieterem czytającym jego treść, a na ekranie wyświetlano tylko odpowiedzi. Ankieta ta reprezentowała najwyższy poziom wprowadzonych zabiegów humanizujących i była pod tym względem zbliżona do CAPI, czyli ostatniej z technik zastosowanych w badaniu, w której to ankieter rozmawiał z respondentem podczas kontaktu face-to-face a wywiad był wspomagany komputerowo. W badaniu brało udział 10 ankieterów (pięć kobiet i pięciu mężczyzn), którzy byli w podobnym wieku jak respondenci (co pozwoliło uniknąć efektu ankieterskiego związanego z różnicami wieku pomiędzy badanymi a ankieterami). Badanych losowo przydzielano do rodzaju użytego narzędzia badawczego.

Sam kwestionariusz składał się tylko z pytań zamkniętych (zarówno pytań dychotomicznych, jak i pytań ze skalą), na podstawie których sporządzono pięć indeksów:

1. Indeks permisywizmu moralnego - zbudowany z 6 pytań badających opinie na temat zachowań moralnie nagannych (np. praca bez umowy, przewóz nielegalnych towa-

${ }^{23}$ Badanie przeprowadzono od grudnia 2016 r. do marca 2017 r. w ramach projektu NCN (nr UMO-2014/15/B/HS6/01386) „Wpływ zabiegów humanizowania procedury badawczej w ankiecie internetowej CAWI na wartość uzyskiwanych danych"; kierownikiem projektu jest dr Katarzyna Grzeszkiewicz-Radulska. Rezultaty tych badań są obecnie analizowane oraz interpretowane i zostaną opisane w publikacjach, które powstaną na zakończenie projektu badawczego. 
rów przez granicę) ze skalą 1-4, gdzie im wyższa wartość tym większy stopień permisywizmu moralnego.

2. Indeks gotowości udzielania szczerych odpowiedzi na pytania zagrożone oceną społeczną - zbudowany w oparciu o 9 dychotomicznych pytań (np. unikanie płacenia podatków, przywłaszczanie sobie znalezionych rzeczy), im wyższa wartość indeksu tym respondenci byli bardziej skłonni udzielać odpowiedzi nienarażonych na ocenę społeczną.

3. Skala aprobaty społecznej - złożona z 29 dychotomicznych pytań, którą opracowano według klucza przyznając 1 punkt za każdą odpowiedź twierdzącą (np. Jestem zawsze uprzejmy, nawet jeśli nie jest mi to na rękę) w przypadku pozycji przedstawiającej zachowanie aprobowane lub za każdą odpowiedź przeczącą w odniesieniu do pozycji przedstawiającej zachowanie nieaprobowane (np. Byty wypadki, kiedy oszukałem kogoś), im wyższy wynik tym większa tendencja do pokazywania się w korzystnym świetle.

4. Indeks egalitaryzmu płciowego - zbudowany z 7 pytań służących pomiarowi stosunku wobec ról kobiet i mężczyzn ze skalą od 0 do 7 (im wyższy wynik tym bardziej profeministyczne nastawienie badanego.

5. Indeks swobody seksualnej - zbudowany z 7 pytań mierzących opinię na temat różnych zachowań seksualnych (np. masturbacji, seksu grupowego) ze skalą od 1 do 7 , gdzie im wyższy wynik tym bardziej permisywne nastawienie.

Dodatkowo mierzono również wystąpienie satisficingu ${ }^{24}$, czyli wybierania odpowiedzi zgodnie z zasadą, by nie podejmować niepotrzebnego wysiłku przy jednoczesnym udzielaniu odpowiedzi na pytania. Respondenci stosujący tę strategię nie odmawiają odpowiedzi i nie rezygnują z udziału w badaniu, ale niejako „markują” ten udział poprzez wybieranie odpowiedzi spośród zaproponowanych alternatyw, stwarzając tym samym pozory dostarczania odpowiedzi przemyślanej. O przyjęciu takiej strategii mogą świadczyć: wybór pierwszej alternatywy, która wydaje się rozsądna (przez co pojawia się efekt pierwszeństwa); potakiwanie, czyli udzielania odpowiedzi wyrażających zgodę z twierdzeniem zawartym w pytaniu; niezróżnicowanie oceniania obiektów w pytaniach, w których jest dużo obiektów do oceny; udzielanie odpowiedzi typu „trudno powiedzieć” zamiast prezentowania posiadanej opinii; zgadzanie się z twierdzeniami, które głoszą potrzebę utrzymania status quo i unikanie takich, które popierają wprowadzenie zmian, losowy wybór odpowiedzi spośród alternatyw w kafeterii.

Podstawy teoretycznej tych badań należy szukać w rozważaniach na temat tego, w jaki sposób nowoczesne technologie pomagają badaczom sondażowym ograniczać błędy, efekty czy wpływy, które w tych badaniach występują. Postawiliśmy sobie pytanie: czy pewne elementy procedury badawczej (zastępujące ankietera w jego czynnościach a nawet imitującego jego obecność, które nazywa się zabiegami humanizującymi) wprowadzone do ankiet komputerowych pozwolą na wzbudzenie w respondencie przeświadczenia społecznej obecności drugiego człowieka? A co za tym idzie, czy uda się wprowadzić do CAWI wszystkie korzyści związane z obecnością ankietera a wyeliminować wady, które mogą skutkować pojawieniem się efektu ankieterskiego. Same zabiegi humanizujące pozwalają na zwiększenie interaktywności narzędzia dzięki: sterowaniu regułami przejścia, realizacji

\footnotetext{
${ }^{24}$ J. Krosnick, Response strategies for coping with the cognitive demands of attitude measures in surveys, "Applied Cognitive Psychology” 1991, Vol. 5; J. Krosnick, Survey research, “Annual Review of Psychology" 1999, Vol. 50.
} 
zasady pytanie za odpowiedź, wysyłaniu spersonalizowanych komunikatów zwrotnych, nawiązywaniu do udzielonych odpowiedzi itp. Dodatkowo można wprowadzać do ankiety reprezentację ankietera używając np. jego zdjęcia, głosu, filmu czy nawet tworząc postać wirtualnego ankietera będącego np. awatarem, animowanym rysunkiem itp. Za wykorzystaniem tych zabiegów w praktyce badawczej stoi chęć mobilizowania respondentów i ich uwagi, a także oczekiwanie, że CAWI stanie się ,idealną" techniką badawczą, zdolną łączyć zalety tradycyjnej ankiety oraz wywiadu face-to-face, w której zminimalizowane zostanie ryzyko efektu społecznej poprawności, efektu ankieterskiego oraz wkładania niewielkiego wysiłku poznawczego w proces udzielania odpowiedzi.

Sam problem - stworzenia techniki idealnej, czyli odpornej na wszelkie zakłócenia nie jest wcale nowy, ale sposób jego realizacji jest nowatorski, ponieważ zastosowano w nim możliwości technologiczne, które jeszcze kilka lat temu były niewykonalne. Tworzenie i przesyłanie kwestionariuszy z elementami video stało się możliwe m.in. dzięki coraz to lepszym łączą internetowym $\mathrm{z}$ dużą przepustowością. Biorąc pod uwagę ogrom technicznych czynności, które musi wykonać badacz w fazie przygotowawczej (nagranie filmów, odpowiednie ich zmontowanie, połączenie plików wideo ze skryptem komputerowym), nie sądzę, by tego typu badania były stosowane zbyt często. Na pewno nie jest to rozwiązanie dla firm badawczych dążących do redukcji kosztów przy jednoczesnym przyspieszeniu fazy terenowej. Widzę jednak szansę na prowadzenie takich prób w obszarze metodologii badań empirycznych, gdy socjologowie będą np. zainteresowani pomiarami wielkości poszczególnych błędów, którymi obarczone są rezultaty badań.

\section{INNOWACJE SPOZA DZIAŁALNOŚCI BADAWCZEJ}

Czasami badacze społeczni swoich inspiracji szukają poza nauką zwracając się ku tym, którzy na co dzień działają i funkcjonują w rzeczywistości społecznej. Jednym z takich przykładów przeniesienia procedur deliberacyjnych na grunt naukowy są próby ich wykorzystania w badaniach socjologicznych. Zanim opiszę dokładniej, na czym polegały takie innowacje, postaram się przybliżyć same procedury deliberacyjne, które na użytek tego opracowania, ale również we wcześniejszych moich artykułach nazwałam technikami deliberacyjnymi. Odwołując się do książki Deliberacja. Teoria - metodologia - praktyka przyjmuję, że techniki deliberacyjne są utrwalonymi i spisanymi dyrektywami dotyczącymi wzorów czynności, które muszą zostać wykonane (przez badacza i jego współpracowników), aby zrealizować pewne zadania badawcze. Główną rolę w tym postępowaniu odgrywa deliberacja „będąca pogłębioną, zbiorową dyskusją, namysłem prowadzonym przez równych sobie i wolnych od przymusu uczestników" ${ }^{25}$. Tylko dyskusje, które - podając za Jürgenem Habermasem - są prowadzone w oparciu o przyjęte na ich początku reguły i umożliwiające ,bezstronny i spójny osąd w kwestiach praktycznych”"26 można nazwać deliberacjami. Dodatkowo podaje się jeszcze kilka innych cech, które charakteryzują tego typu debaty, a mianowicie mają one:

1. Argumentatywny charakter, czyli należy zaopatrywać wszystkie wypowiedzi w odpowiednie argumenty ukazujące różne punkty widzenia danej sprawy, prezentujące wszystkie za i przeciw, nieograniczające się tylko do jednostronnej interpretacji.

\footnotetext{
25 A. Krzewińska, Deliberacja. Teoria - metodologia - praktyka, Łódź 2016, s. 11.

26 J. Habermas, Faktyczność i obowiazywanie. Teoria dyskursu wobec zagadnień prawa i demokratycznego państwa prawnego, Warszawa 2005, s. 328.
} 
2. Ujawniać wszystkie stanowiska, opinie zakazuje się w ich trakcie „kneblowania określonych poglądów" i pozwala na udział w deliberacjach wszystkich zainteresowanych stron. Dodatkowo każdy z uczestników powinien „na wejściu” otrzymać taki sam zasób informacji na dany temat, nie ma bowiem w deliberacjach miejsca na propagandowe chwyty, indoktrynowanie czy narzucanie zdania.

3. Inkluzyjny charakter, a więc pozwalają na wzięcie udziału w dyskusji nie tylko tym, którzy potrafią deliberować, posiadają wiedzę na temat przedmiotu debaty, ale również osobom żywo zainteresowanym daną sprawą, ale niekoniecznie przygotowanym do udziału od strony posiadanych kompetencji komunikacyjnych. Deliberacje są otwarte na „osoby o odmiennych cechach osobowościowych i światopoglądzie, pochodzące z rozmaitych środowisk, grup społecznych itd.”27. W dyskusjach nie są ważne: wpływy, stanowiska, status materialny, znajomości. Wszystkim zagwarantowane jest nie tylko uczestnictwo, ale również prawo do bycia wysłuchanym.

4. Być wolne zarówno od zewnętrznych i wewnętrznych przymusów, a ich ,regulatorami” są przyjęte na ich początku i obowiązujące wszystkich uczestników zasady.

5. Być kontynuowane bez ograniczeń, a nawet mogą być wznawiane w dowolnym momencie. Prowadzone są najczęściej na tematy spraw wspólnych dla wszystkich członków danej zbiorowości i zaleca się ich stosowanie w sytuacjach, gdy „mamy do czynienia z ograniczonymi zasobami i z góry wiadomo, że nie ma możliwości zaspokojenia potrzeb każdej ze stron konfliktu"28.

6. Zastosowanie w rozważaniu kwestii z wielu dziedzin życia, o różnym zasięgu geograficznym: od lokalnych dotyczących jednego budynku, ulicy po ponadnarodowe np. odnoszące się do obywateli Unii Europejskiej. Deliberacja wymuszają ogniskowanie uwagi na tym, co łączy ludzi.

Nie wszystkie dyskusje oparte na procesie deliberacji przebiegają w jednakowy sposób, bowiem mogą być one elementem bardzo różnych procedur, wśród których najbardziej popularne ${ }^{29}$ są: sondaż deliberatywny (Deliberative Polling), sądy obywatelskie (Citizens Jury), spotkania miejskie XXI wieku (21 st Century Town Meeting), techniki otwartej przestrzeni (Open Space Technology) i kawiarenka deliberacyjna (World Café).

Autorem i propagatorem sondażu deliberatywnego jest Jamesa S. Fishkin, który zorganizował pierwszy takie badanie w roku 1994, a do dziś przeprowadził ponad 30 sondaży. Badanie jest połączeniem pomiarów opinii za pomocą standaryzowanych narzędzi badawczych przeprowadzanych przed deliberacją i po jej zakończeniu oraz dyskusji w na temat możliwych rozwiązań ważnej kwestii, o którą pyta się również w trakcie badania ilościowego. W dyskusjach uczestniczy reprezentatywna próba, którą losuje się spośród uczestników pierwszego sondażu (będących również reprezentacją pewnej populacji), dzięki czemu otrzymane rezultaty można uogólniać. Prowadzenie takiego sondażu zakłada, że zostaną podjęte określone działania, a do najważniejszych z nich należą: czynności organizacyjne

${ }^{27}$ M. Zgiep, Namyst - rozmowa - działanie. Teoretyczny model publicznej deliberacji, „Przegląd Socjologiczny" 2013, t. LXII/4, s. 52.

28 A. Krzewińska, A. Kubiak, Sondaż deliberatywny - inwentarz problemów, „Przegląd Socjologiczny" 2012, t. LXI/1, s. 12.

${ }^{29}$ Popularność tych technik należy rozumieć na dwa sposoby: po pierwsze - są to techniki dobrze opisane w literaturze, po drugie - techniki te najczęściej poleca się jako odpowiednie do stosowania w konsultacjach społecznych, po trzecie - dają możliwość zastosowania ich do różnych tematów, różnych grup, różnych miejsc. 
(np. skompletowanie zespołu badawczego, pozyskanie sponsorów i przedstawicieli mediów; wynajęcie miejsca, w którym będzie prowadzona deliberacja), wylosowanie reprezentatywnej próby i zrealizowanie badania opinii (sondaż zerowy), wylosowanie podpróby (spośród uczestników ,sondażu zerowego”) i zaproszenie ich do uczestnictwa w deliberacji, przygotowanie i dostarczenie potencjalnym uczestnikom deliberacji materiałów informacyjnych na temat przedmiotu debaty, zatrudnienie i przeszkolenie facylitatorów odpowiedzialnych za prowadzenie dyskusji w podgrupach, przeprowadzenie samej debaty i sesji plenarnych, dokonanie drugiego pomiaru opinii. Efektem deliberacji powinno być wypracowanie stanowiska dotyczącego przedmioty debaty, jednak jeśli nie jest to możliwe dąży się do wskazania elementów, w których dyskutujący byli zgodni oraz ujawnia się rozbieżne stanowiska.

Sąd obywatelski służy do podejmowania w trakcie kilkudniowej deliberacji decyzji przez grupę osób, dając przy tym możliwość zbadania: co myślą ludzie? jakie posiadają opinie na dany temat? czy i w jaki sposób opinie te moga się zmieniać? W badaniu uczestniczy od 12 do 20 osób i bardzo często osoby wchodzące w skład „ławy przysięgłych” dobierane są losowo i stanowią reprezentację dla respondentów biorących udział w sondażu opinii na temat kwestii, której będzie dotyczył planowany sąd obywatelski. Sędziowie w trakcie deliberacji zarówno uzyskują materiały opisujące różne sposoby rozwiązania danego zagadnienia (na temat którego jest zorganizowana deliberacja), jak i wysłuchują argumentów ,świadków” będących reprezentantami poglądów różnych stron. Efektem takiego sądu powinny być rekomendacje opisujące zalecany sposób rozwiązania kwestii nad którą debatowano.

Spotkania miejskie XXI wieku stosowane są przede wszystkim w pracy ze społecznościami lokalnymi, chociaż bywają również wykorzystywać do dyskutowania nad kwestiami regionalnymi a nawet krajowymi. W takich debatach może wziąć udział nawet kilka tysięcy osób, które podzielona na niewielkie grupy (10-12 uczestników) dyskutują nad ważnymi kwestiami dla danej społeczności. Dodatkowym elementem takich spotkań jest głosowania nad rozwiązaniami, które są efektem tych grupowych dyskusji. To współwystępowanie dwóch procedur: deliberacji i głosowania jest możliwe dzięki wykorzystaniu odpowiednich technologii: tabletów, laptopów, rzutników multimedialnych, ekranów, specjalnych urządzeń umożliwiających oddawanie głosów a także odpowiedniego oprogramowania, dzięki któremu głosy są zliczane i publikowanie zaraz po głosowaniu. Spotkania miejskie XXI wieku najczęściej organizuje się, gdy należy przedyskutować ważne kwestie w następujących obszarach tematycznych: planowanie i rozwój ekonomiczny danej miejscowości, regionu, budżet i rozdzielanie środków publicznych oraz formułowanie polityk społecznych.

Twórcą techniki otwartej przestrzeni jest Harrison Owen, który zawiedziony rezultatami i atmosferą konferencji, którą zorganizował, postanowił opracować taką procedurę spotykania się i debatowania, która czyniłaby tego typu dyskusje twórczymi, ciekawymi i angażowałyby uczestników. Takie spotkania organizuje się wokół jakiegoś ważnego tematu, ale program, podział na grupy, czas potrzebny na dyskusję, harmonogram spotkań i ich miejsce ustalany jest przez uczestników w trakcie pierwszego wspólnego spotkania. Biorący udział sami zgłaszają propozycje wątków tematycznych i zachęcają pozostałych, by przyłączyli się do ich grupy. Do ich obowiązków należy również facylitowanie takiej dyskusji oraz opracowanie raportu z tej debaty. Technika ta jest odpowiednia w sytuacji, gdy grupa osób chce się wymienić posiadaną wiedzą, przedyskutować istotne dla niej zagadnienia i wypracować rozwiązania. Świetnie sprawdza się, gdy sprawa jest złożona, uczestnicy mają 
wysokie i zróżnicowane kompetencje, dyskutowane kwestie są dla nich ważne i wszystkim zależy na tym, by wypracować jakieś stanowisko w danej kwestii.

Rozmowy w kawiarence nawiązują do rozmów prowadzonych na co dzień, podczas których uczestnicy dzielą się swoimi opiniami i wiedzą na ważny dla nich temat. Rozmowy $w$ kawiarence polegają na dyskusjach w niewielkich, 4- lub 5-osobowych grupach prowadzonych w kilku rundach, przy czym w każdej turze siedzą oni przy innym stoliku i rozmawiają z innymi uczestnikami (tych wędrujących uczestników określa się mianem: podróżników lub ambasadorów idei). Dyskusje odbywają się w przestrzeni przypominającej kawiarnię (z kawą, herbatą, muzyką, gwarem rozmów itp.) a deliberujący zapisują swoje pomysły na papierowych obrusach. Wyniki takich rozmów można prezentować w bardzo różny sposób, np. zatrudniając rysownika, który przedstawia za pomocą rysunków pomysły pojawiające się przy poszczególnych stolikach; pokazując notatki na obrusach; zapisując opracowane pomysły na kartkach post-it przyklejonych na specjalnie przygotowanej do tego tablicy, czy pisząc i publikując raport z takiego spotkania.

Oprócz efektów w postaci rekomendacji, zaleceń, wskazówek, sugestii dotyczących kwestii, nad którą prowadzono deliberację, taka dyskusja ,promuje wzajemny szacunek, poprawia zrozumienie problemów, potrzeb i perspektyw drugiej strony, a w rezultacie kształtuje pozytywne nastawienie pomiędzy uczestnikami. Deliberatywne myślenie w kategoriach dobra publicznego buduje poczucie wspólnoty pomiędzy zaangażowanymi osobami. W jego wyniku może nastąpić zbliżenie lub dopasowanie rozbieżnych dotychczas stanowisk. Siły polityczne będą wówczas uzupełniane o tzw. kapitał społeczny w postaci zaufania społecznego, upowszechniania nastawienia na dialog i tolerancję, a także zmniejszania uprzedzeń. Wytwarza się wówczas więź pomiędzy członkami społeczeństwa oraz pomiędzy obywatelami a instytucjami politycznymi. Procesy te są szczególnie ważne dla scalania i konsolidowania nowoczesnych, heterogenicznych społeczności”30.

Próby takich badań (chociaż ciągle nieśmiałe) podejmowane są coraz częściej i to nie tylko przez socjologów, ale również badaczy z innych dziedzin, których interesuje nie tylko poznawanie opinii, ale również uzgadnianie perspektyw. Zdecydowanie więcej tego typu przedsięwzięć organizuje się w krajach z dojrzałym społeczeństwem obywatelskim ${ }^{31}$, gdzie mieszkańcy wykazują zdecydowanie większe zainteresowanie sprawami publicznymi. Sądzę więc, że techniki deliberacyjne nie staną się bardzo popularną techniką badawczą i nie zastąpią innych technik (chociażby zogniskowanych wywiadów grupowych).

\section{ZAKOŃCZENIE}

Odnosząc innowacje do metodologii badań społecznych, a w szczególności do technik otrzymywania materiałów można mówić o różnych ich poziomach. Najniższym, ale również najłatwiejszym do przeprowadzenia i wymagającym najmniejszego nakładu pracy, jest przyjęcie na grunt własnej dziedziny naukowej określonej techniki (ugruntowanej, w wystarczającym stopniu sprawdzonej i przetestowanej w badaniach metodologicznych) zastosowanej w innej dyscyplinie. Wysiłki badaczy dokonujących takiego ,przejęcia” ogniskują

${ }^{30}$ E. Wesołowska, Deliberatywne rozwiązywanie konfliktów wartości. Wielość dróg do porozumienia, Olsztyn 2010, s. 32.

${ }^{31} \mathrm{O}$ ograniczonych możliwościach stosowania tego typu technik pisałam m.in. w artykule „Słabości i niedostatki procedur demokracji deliberacyjnej” zamieszczonym w „Przeglądzie Socjologicznym" 2017, LXVI/3, s. 45-72. 
się wtedy na sprawdzeniu, czy dana technika może być użyta do badania określonej problematyki i czy zebrane przy jej zastosowaniu dane pozwolą udzielić odpowiedzi na pytania problemowe. Innowacyjność będzie wtedy związana przede wszystkim z dostrzeżeniem potencjałów danej techniki i możliwości jej użycia do nowych pól badawczych. Takim innowacjom będą polegały przede wszystkim te techniki, które przenoszone są z innych dziedzin naukowych a czasami także spoza działalności naukowej (np. techniki deliberacyjne po odpowiednim metodologicznym sprawdzeniu). Drugi poziom innowacji wymaga od badaczy pewnego wysiłku, pomysłowości i inwencji, bowiem polega na adaptacji, czyli twórczym wprowadzeniu zmian mających na celu dostosowanie danej techniki do potrzeb konkretnego badania lub wprowadzenie tych zmian w sposób trwały. Z takimi innowacjami mamy na przykład do czynienia w przypadku zastosowania nowoczesnych technologii w znanych i ugruntowanych technikach (CATI lub CAPI). Często źródłem takich innowacji są firmy badawcze prowadzące badania komercyjne ${ }^{32}$, którym zależy na usprawnieniu procedury badawczej, a co za tym idzie - zmniejszeniu środków przeznaczanych na realizację. Kolejny poziom związany jest $\mathrm{z}$ faktycznym stworzeniem nowej, innowacyjnej techniki, nowego nieznanego wcześniej podejścia. W obecnej sytuacji z takim rodzajem innowacji mamy do czynienia niezmiernie rzadko $^{33}$, a analizy metodologiczne pokazują, że większość innowacji związanych jest $\mathrm{z}$ wprowadzaniem zmian $\mathrm{w}$ istniejących już procedurach ${ }^{34}$. Wprowadzanie kolejnych innowacji w obrębie technik otrzymywania materiałów będzie jak przypuszczam - dalej związane z rozwojem technologicznym i dostosowaniem istniejących już technik do urządzeń mobilnych i nowych aplikacji. Jednak kierunki tych zmian są niezmiernie trudne do przewidzenia i jest to raczej zadanie dla futurologa niż socjologa zajmującego się metodologią badań.

Nawet, jeśli w literaturze metodologicznej pojawiają się doniesienia dotyczące innowacyjnych podejść badawczych, to najczęściej są to zbyt szybko ogłoszone sukcesy metodologiczne, gdyż badacze dzielą się swoimi „odkryciami” najwyżej po kilkukrotnym przetestowaniu danej metody. Być może moje podejście jest wyrazem pewnego „metodologicznego usztywnienia", jednak uznanie pewnego sposobu postępowania badawczego i nadanie mu nazwy techniki badawczej powinno być poprzedzone - moim zdaniem - wieloma próbami empirycznymi, próbami badań prowadzonych przez różnych badaczy (z różnych środowisk), refleksją metodologiczną związaną również z ustaleniami dotyczącymi założeń ontologicznych i epistemologicznych danego podejścia. Brak takiej refleksji może powodować, że te metodologiczne innowacje zamiast odpowiadać na potrzeby, dostarczać rozwiązań, przyczynią się - jeśli nie do powstania nowych trudności badawczych - to bynajmniej nie rozwiążą się starych badawczych dylematów. W takiej sytuacji - parafrazując tytuł artykułu Maxa Traversa - będziemy mieć jednocześnie do czynienia z nowymi metodami i starymi problemami ${ }^{35}$.

32 P.B. Sztabiński, F. Sztabiński, Z. Sawiński, Wstęp [w:] Nowe metody, nowe podejścia badawcze w naukach spotecznych, red. P.B. Sztabiński, F. Sztabiński, Z. Sawiński, Warszawa 2004, s. 5-9.

${ }^{33}$ Wśród często wymienianych innowacyjnych metod badawczych znalazła się netnografia, której twórcą jest R.V. Kozinets. Więcej informacji na temat tej metody można znaleźć w książce Netnografia. Badania etnograficzne online.

${ }^{34}$ R. Willes, A. Bengry-Howell, G. Crow, M. Nind, But is it innovation? The development of novel methodological approaches in qualitative research, Methodological Innovations Online, 2013, Vol. 8, No. 1, p. 18-33.

35 M. Travers, New methods, old problems: A sceptical view of innovation in qualitative research, "Qualitative research" 2009, Vol. 9, No. 2, p. 161-179. 


\section{LITERATURA}

1. Banks M., Materiaty wizualne w badaniach jakościowych, Wydawnictwo Naukowe PWN, Warszawa 2009.

2. Bednarowska Z., Desk research - wykorzystanie potencjatu danych zastanych w prowadzeniu badań marketingowych i społecznych, „Marketing i Rynek” 2015, nr 7.

3. Bloom J., The Speech IVR as a Survey Interviewing Methodology [w:] Envisioning the Survey Interview of the Future, red. F.G. Conrad, M.F. Schober, John Wiley \& Sons, New York 2008.

4. Couper M.P., Technology and the survey interview/questionnaire, Conrad F.G., Schober M.F. (ed.), Envisioning the survey interview of the future, John Wiley \& Sons, New York 2008.

5. Greenwood D.J., Action research, czyli o badaniach w dziataniu [w:] Badania jakościowe. Podejścia i teorie, D. Jemielniak, Wydawnictwo Naukowe PWN, Warszawa 2012.

6. Grzeszkiewicz-Radulska K., Krzewińska A. Wykorzystanie nowoczesnych technologii $w$ ankietach wspomaganych komputerowo [w:] Technologiczno-spoteczne oblicza XXI wieku, red. D. Gałuszka, G. Ptaszek, D. Żuchowska-Skiba, Wydawnictwo LIBRON - Filip Lohner, Kraków 2016.

7. Habermas J., Faktyczność i obowiązywanie. Teoria dyskursu wobec zagadnień prawa i demokratycznego państwa prawnego, Wydawnictwo Naukowe Scholar, Warszawa 2005.

8. Jagiełło E., Antropolog w organizacji. Zapiski z badań terenowych, „Etnografia Polska” 2012, t. LVI, z. 1-2.

9. Konecki K., Kultura organizacyjna japońskich przedsiębiorstw przemystowych. Studium socjologiczne, Wydawnictwo UŁ, Łódź 1994.

10. Kostera M., Antropologia organizacji. Metodologia badań terenowych, Wydawnictwo Naukowe PWN, Warszawa 2005.

11. Kozinets R.V., Netnografia. Badania etnograficzne online, Wydawnictwo Naukowe PWN, Warszawa 2012.

12. Krosnick J., Response strategies for coping with the cognitive demands of attitude measures in surveys, “Applied Cognitive Psychology” 1991, Vol. 5.

13. Krosnick J., Survey research, “Annual Review of Psychology” 1999, Vol. 50.

14. Krzewińska A., Stabości i niedostatki procedur demokracji deliberacyjnej, „Przegląd Socjologiczny” 2017, t. LXVI/3.

15. Krzewińska A., Deliberacja. Teoria - metodologia - praktyka, Wydawnictwo UŁ, Łódź 2016.

16. Krzewińska A., Grzeszkiewicz-Radulska K., Klasyfikacja sondażowych technik otrzymywania materiałów, „Przegląd Socjologiczny” 2013, t. 62/1.

17. Krzewińska A., Kubiak A., Sondaż deliberatywny - inwentarz problemów, „Przegląd Socjologiczny" 2012, t. LXI/1.

18. Lutyński J., Metody badań społecznych, ŁTN, Łódź 1994.

19. Mulgan G., Social innovation: What it is, Why it matters, How it can be accelerated, Basingstoke Press, London 2006.

20. Olejniczuk-Merta A., Innowacje społeczne, „Konsumpcja i Rozwój” 2013, nr 1.

21. Sikorski Cz., Miasta, kultury, organizacje, Wydawnictwo WSHE, Łódź 2005. 
22. Sztabiński P.B., Sztabiński F., Sawiński Z., Wstęp [w:] Nowe metody, nowe podejścia badawcze $w$ naukach społecznych, red. P.B. Sztabiński, F. Sztabiński, Z. Sawiński, Wydawnictwo IFiS PAN, Warszawa 2004.

23. Travers M., New methods, old problems: A sceptical view of innovation in qualitative research, "Qualitative research" 2009, Vol. 9, No. 2.

24. Wesołowska E., Deliberatywne rozwiązywanie konfliktów wartości. Wielość dróg do porozumienia, Wydawnictwo Uniwersytetu Warmińsko-Mazurskiego, Olsztyn 2010.

25. Willes R., Bengry-Howell A., Crow G, Nind M., But is it innovation? The development of novel methodological approaches in qualitative research, "Methodological Innovations Online" 2013, Vol. 8, No. 1.

26. Wronka-Pośpiech M., Innowacje społeczne - pojęcie i znaczenie, Studia Ekonomiczne. Zeszyty Naukowe Uniwersytetu Ekonomicznego w Katowicach, nr 212/2015.

27. Zgiep M., Namyst - rozmowa - działanie. Teoretyczny model publicznej deliberacji, „Przegląd Socjologiczny" 2013, t. LXII/4.

\section{NETOGRAFIA}

1. Blumberg S.J., Cynamon M.L., Respondent Acceptance of Touch-Tone Data Entry in Cognitive Interview on HIV/STD Behaviors, www.fcsm.gov/99papers/ 2000 (dostęp: 25.06. 2013 r.).

2. McKay R.B., Robinson E.L., Malik A.B., Touch-Tone Data Entry for Household Surveys: Research Findings and Possible Applications, www.bls.gov/ore/pdf/cp940080.pdf 1994 (dostęp: 25.06.2013 r.).

3. Robertson K.W., Hatch-Maxfield J., Data Collection in the U.S. Bureau of Labour Statistics' Current Employment Statistics Survey, wystąpienie przygotowane na konferencję w Genewie (31 października - 2 listopada), Seminar on New Frontiers for Statistical Data Collection, http://www.unece.org/fileadmin/DAM/stats/ 2012, (dostęp: 25.06.2013 r.).

4. Xenitidou M., Gilbert N., Innovations in social research methods, University of Surrey, 2009, http://epubs.surrey.ac.uk/id/eprint/2271 (dostęp: 15.11.2017 r.).

\section{INNOVATIONS IN THE SOCIAL RESEARCH}

The innovations result from the evolution of phenomena both social as well as economic ones. The new phenomena, so interesting for researchers, often may not be studied by using the old methods. The cause for: incompatibility of the measuring apparatus on the one hand, incompatibility of research procedures to the new phenomena on the other hand. When phenomena are not compatible with the research methods, sociologists could cope with this problem in two ways: abandon the research or change something in the methodology. The first strategy is used very rarely, while the second one is a source of implementation of innovations in the methods of social research.

The paper discusses changes, which happen in the widely understood social research and are connected with innovations of instrumentation of social research. The paper focuses on the trends of these changes and the assessment of influence on the quality of social research and data collection.

The changes in the social research could be varied, but the researchers could face: modifications of existing research techniques which are connected with advanced technology (modes of data collection supported by computers), implementation of new data collection modes 
from other sciences or from unscientific practices (deliberative techniques), methodological formulation of the used previously procedures, which are now called the data collection modes (autoethnography), and the distinction during the process of conducting particular research parts of the process and terming them the research technique (desk research).

Keywords: innovations, social research, techniques of research, methodology of social research.

DOI: $10.7862 /$ rz.2018.hss.44

Przestano do redakcji: grudzień $2017 r$.

Przyjęto do druku: wrzesień 2018 r. 